\section{Riisager i Seattle}

Af professor Louis Christensen

\section{1972 blev komponisten Knudåge Riis-} ager udnavnt til aresdoktor i Seattle. I anledning af Det Kongelige Biblioteks fremstod i forbindelse med 100-airet for Knudage Riisagers fodsel beskriver en af initiativtagerne bag doktorpromoveringen $i$ 1972, den danskfodte amerikanske musikprofessor Louis Christensen begivenhedenen begivenhed, der ellers ikke har varet grundigt dokumenteret tidligere.

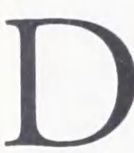
er kom et postkort. Det viste et smukt billede af Den Lille Havfrue med en flot sommersolnedgang som baggrund. Det var fra min ven Mikael Scheremetiew som var i København i sommeren 1971 og som havde noget på hjerte til mig i Seattle, noget der ikke kunne vente. Der stod kort og godt at han havde været sammen med Knudåge Riisager, havde inviteret ham til at komme til Seattle og at denne i princippet havde accepteret.

Mine øjebryn krøb opad. Det syntes som den rene umulighed, at en af Danmarks allerstørste komponister og tidligere direktør for Det Kongelige Danske Musikkonservatorium ville komme hele vejen til U.S.A.s vestkyst. På den anden side var der intet, der var umuligt for Mikael. Han kendte og anerkendte ingen grænser, ikke i sin kunstglæde, ikke imellem aldersgrupper eller sociale lag, ikke imellem nationaliteter - kun dét at stræbe efter den højeste kvalitet $\mathrm{i}$ alle henseender gjaldt for ham, og da ganske særligt når det havde med musik at gøre.

\section{Introduktion}

$\mathrm{M}$ ikael havde været professionel musiker i sin ungdom - oprindeligt "wunderkind" - i

Sverige, hvortil hans del af den velkendte russiske familie var udvandret. For Mikael var det centrale i musikken ikke korrekt nodelæsning, men ånden i det, der blev spillet. Så han sagde farvel til den professionelle musik, udvandrede til. U.S.A. og hengav sig til amatørmusik. Som han yndede at sige: "En amatør betyder ikke én der ikke kan spille, det betyder én der elsker at spille!" I Seattle havde han opbygget en stor organisation, Thalia, der efterhånden omfattede symfoniorkester, kammerorkester, strygekvartet og diverse kammermusikensembler, to ungdomsorkestre, en sommermusiklejr o.m.a. Når familierne til de unge mennesker blev talt med, blev henved tusind mennesker involveret.

Sidst i tredserne lykkedes det for Seattle Universitet at få Thalias symfoniorkester officielt tilknyttet som "orchestra-in-residence", og der fulgte nogle dejlige år med musikbegejstring, hvor Scheremetiew altid søgte at fremføre kvalitetsmusik af ukendte komponister eller mindre kendte værker af "de store." I den forbindelse oparbejdede han et anseligt bibliotek - med dybde og bredde der også omfattede en grafisk kunstsamling. Ydermere søgte han musik til ungdomsorkestrene, der både var lødig og mindre teknisk krævende.

Som følge af disse bestræbelser kom Mikael i forbindelse med Knudåge 


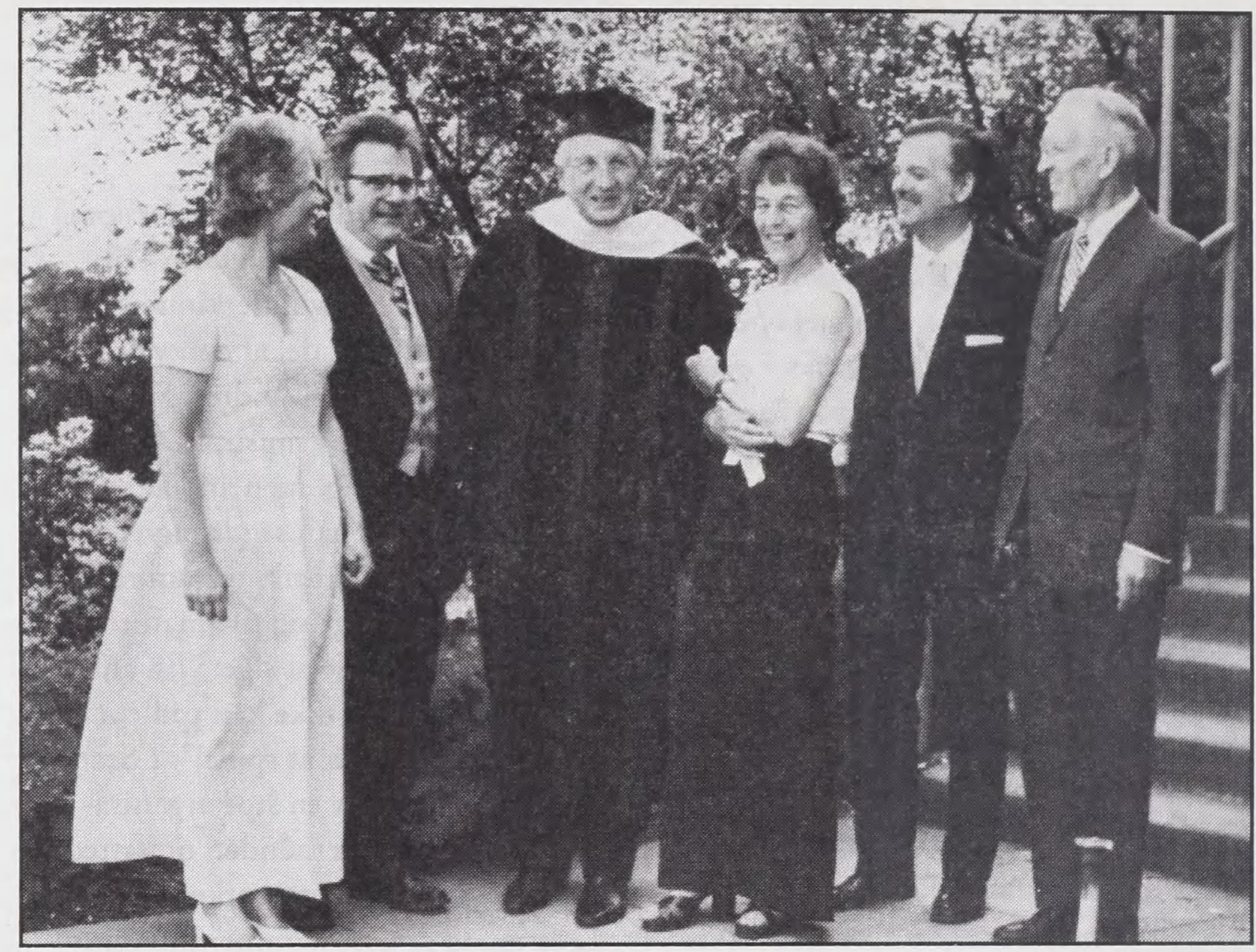

Riisager i fuldt ornat efter doktorpromoveringen i Seattle d. 12. maj 1972. De ovrige er: t.h. for Riisager Frances Walton og Mikael Scheremetiew fra Thalia og t.v. for Riisager komponistens hustru Ase Riisager, denne artikels forfatter samt højesteretsdommer Theodore Turner.

Riisager. Han fortalte mig senere hvordan det var gået til. Det begyndte med en telefonopringning. Mikael forklarede komponisten, hvad det drejede sig om. "Hvor ringer De fra?" - havde Riisager spurgt. "Fra en telefonboks på Rådhuspladsen." "Bliv hvor De er, jeg kommer og henter Dem i en taxa." Og snart gik musiksnakken løs i Riisagers og fru Åses hjem på Frederiksberg. Mikael berettede med forundring om et dejligt træk ved komponistens væremåde, som nok mange, der kendte ham, kunne bekræfte. Han kunne finde oprigtig glæde ved de enkleste ting og situationer - sådan helt "H. C. Andersensk." Riisager vendte sig på et tidspunkt i samtalen mod Åse og sagde med store øjne: "Han ka' li' min musik!" Her var en af landets mest anerkendte komponister, hvis balletter blev fremført internationalt, hvis sange var kendt af alle danskere, og han udtrykte en frisk glæde ved, at en mand helt fra Stillehavets kyst syntes om hans musik. Det var i løbet af den samme inspirerede eftermiddag, at invitationen blev udstedt.

\section{Forspil}

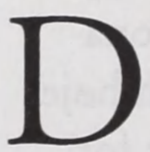

a Mikael kom tilbage, mødtes vi og talte om det spændende forehavende. Det var i første række 
et Thaliaprojekt $\mathrm{i}$ alle dets mange forgreninger, men Mikael vidste jo, at jeg ville tage alt, der havde med Riisager at gøre, meget personligt. Jeg spurgte ham, om det nu også var en sikker sag eller om det måske var mere i retning af en drøm. Han svarede at de hundredevis af folk fra ungdomsmusikorganisationerne måtte igang med at sælge chokoladeæsker og luksussæbe og at de nok skulle klare at indsamlinge de økonomiske midler. Så forklarede jeg ham, hvorfor jeg spurgte, hvortil han reagerede som jeg havde gjort det på det oprindelige postkort.

I de år var jeg afdelingsleder ved Institut for "Fine Arts" på Seattle Universitet, og samme efterår begyndte jeg at undersøge proceduren for, at Knudåge Riisager kunne modtage en akademisk æresbevisning under sit ophold i Seattle - et ophold, jeg opfattede som historisk. Først måtte de ikke-musikkyndige administratorer overbevises om gæstens værdighed til at modtage en sådan æresbevisning og det blev nødvendigt at samle en hel del materiale til belysning af emnet og til sidst blev der sendt en formel ansøgning. Gradvist gik forslaget gennem universitetets styrelsesorganer, og før juleferien havde man godkendt, at Riisager kunne blive dets første Doctor of Music, honoris causa. Universitetets rektor Louis Gaffney, S.J. (Jesuitterordenen, som ejer Seattle Universitet) tog dermed en beslutning, der var en akademisk statsmand værdig. Der var intet fortilfælde $\mathrm{i}$ at tilknytte en udenlandsk komponist institutionen, og så vidt vides var det den første æresdoktorgrad i musik i staten. Alle hensyn var idealistiske og uden åbenbare umiddelbare fordele.

Tilfældigvis skulle jeg $\mathrm{i}$ anden anledning på en rejse til Californien netop på denne tid. Jeg fik en aftale med generalkonsul Per Frellesvig ved Danmarks Generalkonsulat på U.S.A.s vestkyst, som dengang var placeret i San Francisco. Da dagen oprandt, var vejret perfekt og udsigten over den berømte bugt fra Alcoa-bygningen var betagende. Generalkonsul Frellesvig var yderst imødekommende og så med det samme denne begivenhed som ikke alene en fortjent æresbevisning til Riisager, men samtidig som en fin anerkendelse af dansk kultur i det fremmede, og han afgav løfte om sin tilstedeværelse ved doktorpromoveringen. Ydermere viste det sig, at Per Frellesvig var musikkyndig og bratschist, så adskillelige emner blev berørt den eftermiddag.

I den mellemliggende tid løste Thalia-organisationen, som Mikael havde forudsagt, alle de praktiske opgaver. En tidsplan voksede gradvist frem for det fire uger lange besøg, under hvilket Riisager og fru Ase skulle bo i Mikael Scheremetiews centralt beliggende hus, som meget praktisk også fungerede som hovedkvarter for Thalia.

\section{Ouverture}

ikken stemning der var i lufthav-

nens modtagelsesværelse fredag $d$. 28. April, 1972! Der var - foruden et opbud af Thalias ledere og yngste musikere - repræsentanter for byens danske organisationer og Seattle Universitet.

Næste dag kunne man læse i avisen:"Musik og blomster hilste Knud- 


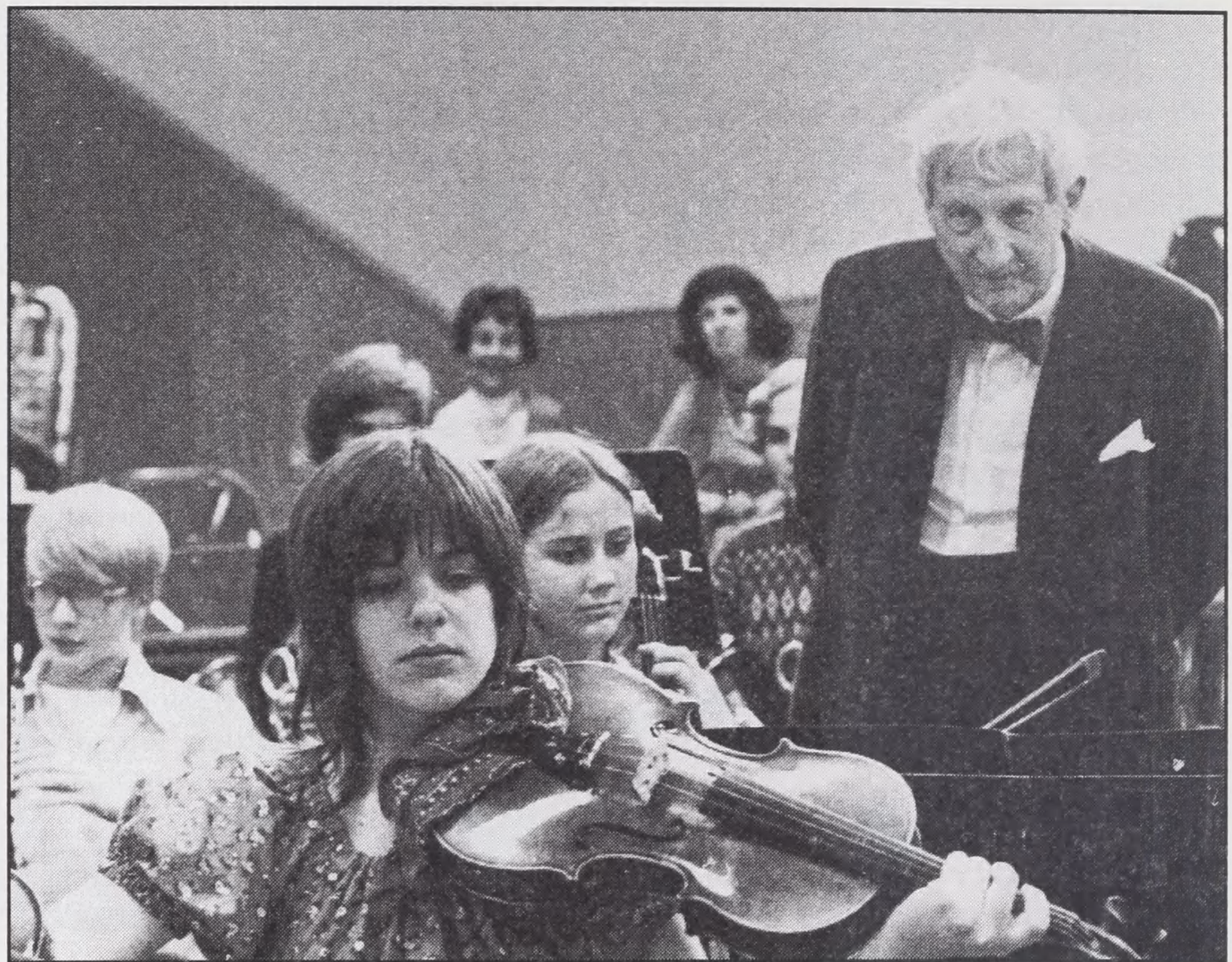

Riisager som opmerksom tilhorer under proverne med Thalia's ungdomsorkester i maj 1972.

åge Riisager, Danmarks ledende nulevende komponist og hans hustru Åse velkommen ved deres ankomst fra København til Sea-Tac lufthavn igår.

Musikken kom fra 30 violinister $\mathrm{i}$ en alder fra fire til nitten, som spillede et arrangement af et af hans temaer, og blomsterne blev overrakt af femårige George $\mathrm{Hu}$, som var udvalgt blandt de 400 unge, der er en del af Thalia Artists. [...] Riisager var synligt rørt, da han sammen med sin hustru, en anerkendt kunstmaler, stod og lyttede til de unge."

Tidsplanen gav gæsterne lejlighed til at hvile ud efter rejsens strabadser, hvorefter der fulgte en uge med prø- ver i de forskellige instrumentalgrupper, før det gik løs med koncerter og officielle arrangementer. Her må det indskydes, at Thalias succes naturligvis ikke beroede på en enkelt person. Intet kan beskrive, hvad Frances Walton betød og forsat betyder for organisationen. Frances, cellist, komponist og dirigent, var Mikaels naturlige medarbejder, og hun delte hans kunst- og menneskeglæde med overvældende energi og entusiasme. Mikael og Frances var mere som kunstneriske forældre for alle, der havde med Thalia at gøre, ikke mindst i ungdomsorkestrene og på sommerlejren. Knudåge og Åse blev hurtigt nære venner af Fran- 
ces, som de allerede var det med Mikael. Frances vakte Riisagers interesse for amerikansk musik, især folkemusikken, og det resulterede senere i en komposition, suiten over amerikanske folkemelodier. Han var efter sigende specielt begejstret for "Turkey in the Straw".

En aften stødte jeg til firkløveret Knudåge, Åse, Mikael og Frances efter en prøve. Ved denne lejlighed var der en amerikaner, der spurgte Ase:"Hvad er Deres indtryk af amerikanerne?" Efter at have tænkt sig om svarede hun:"Jeg synes folk er rare mod hinanden her." Hun havde nøje lagt mærke til, hvordan familierne og musikerne $i$ alle aldre omgikkes hinanden i en atmosfære af hjertelighed.

\section{Intrada: Gaudeamus}

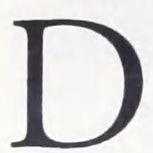
en 12. maj klokken tolv, nøjagtig to uger efter Knudåge og Åse Riisagers ankomst til Seattle, fandt doktorpromoveringen sted på Seattle Universitet.

I den akademiske indgangsprocession var hovedpersonen iført én af de lange sorte kapper med de mangefarvede hætter over skuldrene, der angiver afgangsinstitution og akademisk grad, og øverst på hovedet den sorte hat med en flad kvadrat ovenpå og en kvast. Man bevægede sig værdigt op på scenen, der prydedes af Stars and Stripes og Dannebrog og af Thalias symfoniorkester. Alt dette foregik til tonerne af Griegs "Triumfmarch" fra Sigurd Jorsalfar dirigeret af Frances Walton. Derefter fulgte de to nationalsange med andre dirigenter. Min kollega i musikafdelingen, Rev. Kevin Waters, S.J., oplæste en invocation (ind- gangsbøn), hvorefter generalkonsul Per Frellesvig holdt en kort tale på Danmarks vegne. Højtideligheden var, som ret var, præget af musik, og Seattle Universitets A Capella Kor sang først Det Danske Folk på dansk, et værk af min far Niels Christensen, og dernæst Weyses "O Day Full of Grace" (Den signede Dag på engelsk). Jeg var blevet bedt om at forfatte og oplæse en proklamation, som begyndte således: "Seattle Universitet hylder en mand, hvis kompositioner er blevet en del af hans lands kulturarv, men deres kosmopolitiske sprog har samtidig fundet modtagelige ører på musikkens verdenscene." Efter biografiske bemærkninger, der lagde vægt på hans år som konservatorierektor, sluttedes med ordene:"Seattle Universitet overdrager med stolthed sin første æresdoktorgrad i musik til professor Knudåge Riisager, hvis kompositoriske virksomhed har beriget alle mennesker."

Så måtte Riisager op at stå medens universitetets rektor Louis Gaffney, S.J., assisteret af prorektor William Guppy, Ph.D., lagde hætten med universitetets farver, som tilfældigvis er rødt og hvidt, over hans hovede og skuldre. Herefter fulgte urpremieren på æresdoktorens Bold Overture, "Kæk Overture", der er tilegnet Mikael Scheremetiev, som også dirigerede. Komponistens oprindelige titel var Preludio ardito, men Mikael overbeviste Riisager om at Bold Overture var bedre til amerikansk brug. Det "kække" i titlen kom sig af, at komponisten opfattede hele denne lange rejse som en kæk og dristig handling. Derefter fulgte Riisagers spændende Qarrtsiluni baseret på en grønlandsk legende. 
Efter en kort tale af Rektor Gaffney afsluttedes højtideligheden med Brahms' Akademisk Festouverture.

De ca. 400 tilhørere og de mange musikere på scenen var tydeligvis inspireret af det store opbud af kreative kræfter, der var forenet ved denne lejlighed, og naturligvis også af dens internationale perspektiver.

Efter æresdoktorens hjemrejse fik jeg et brev, hvori han bl.a. udtrykte, at han naturligvis var meget glad for hætten, som man i U.S.A. forbinder med akademisk værdighed, men at han gerne ville have den sorte hat med det firkantede "låg", som man i Danmark anser for det vigtigste.

Senere på eftermiddagen indbød Det Kgl. Danske Generalkonsulat med Per Frellesvig som vært til reception på Westin Hotel (dengang Washington Plaza). Her kom foruden højtidelighedens hovedpersoner bl.a. Seattles daværende borgmester, Wes Uhlman, Seattles danske æreskonsul Paul Nielsen, R.D., og repræsentanter for lokale danske organisationer.

\section{Fêtes: Cornucopia}

$\mathcal{O}$ øndag d. 14. Maj kom så det egentlige klimaks på Thalias værtsskab for Knudåge Riisagers besøg i

Seattle. Det bestod af to koncerter i forlængelse af hinanden $\mathrm{kl} .14 \mathrm{og} \mathrm{kl} .16$, der hver især bestod af samtidsmusik. De fandt sted på byens kultur- og forlystelsesområde, Seattle Center. Her blev verdensudstillingen i 1962 afholdt, og byen "arvede" en række bygninger, heriblandt byens vartegn, Space Needle, det $200 \mathrm{~m}$ høje tårn med en overbygning, der ser ud som en "flyvende tallerken". Her findes også sportsarenaer, udstillingsbygninger, operahus og teatre. Et af disse, The Playhouse, er meget velegnet til mindre koncerter, og her blev koncerterne afholdt.

Den første koncert stod i ungdommens tegn med to ungdomsorkestre, East Lake Youth Symphony og Highline Youth Symphony, hjemmehørende i to forstadskommuner. Der blev lagt ud med Beginning Strings (Strygere for Begyndere), et arrangement af Frances Walton over et tema af Riisager. Heri deltog de alleryngste fra fem år og op. Man fortsatte med et af Riisagers mest populære værker, I anledning af... , en suite baseret på danske børnesange. Highlineorkesteret spillede så Riisagers Galop, dirigeret af én af de unge musikere. De to orkestre forenede kræfterne i et svensk stykke, Lars-Erik Larssons Pastoral Suite. Så var der en præsentation, hvor æresgæsten modtog en hyldest fra de tilstedeværende musikere og publikum. Koncerten afsluttedes med Carl Nielsens Flojtekoncert med East Lake orkesteret, og begge deltog i Riisagers Sommerrhapsodi, en suite af danske folkesange, der har sommer som det fælles tema.

Efter en kort pause fulgte dagens anden koncert, der med få undtagelser blev gennemført af Thalia Symfoniorkester, som opførte Bold Overture og Qarrtsiluni og East Lake Youth Symphony, som opførte Carl Nielsens Flojtekoncert. Til disse blev der føjet amerikansk musik, en opførelse af Samuel Barbers to Essays for Orchestra. Begge koncerter var en stor succes for arrangørerne. 
Der ligger imidlertid også en anden fortjeneste i det omfattende program, idet skandinavisk musik dengang nær sagt aldrig blev spillet offentligt, og selvom der i de forløbne femogtyve år er sket fremskridt hvad dette angår, står disse koncerter i tilbageblik stadigvæk som en stor begivenhed for nordisk musik. Som et led i finansieringen af disse arrangementer blev der solgt souvenirprogrammer, der på forsiden var prydet med en fin tegning af Otto C. fra 1967. Tegningen viser Riisager ved arbejdsbordet med pennen $\mathrm{i}$ hånden og piben $\mathrm{i}$ munden, og der ses også en blæksuger, en af de gamle halvrunde med en messingknop ovenpå, der brugtes på kontorer helt op gennem halvtredserne til at fjerne vådt blæk med. Ifølge et brev fra Riisager efter hjemkomsten $\mathrm{i}$ juni havde Otto C. tegnet ham, medens han arbejdede på en ballet til daværende Kronprinsesse Magrethes og Prins Henriks bryllup. Dronningen ejer originalen, men Otto C. havde lånt den med henblik på kopiering til souvenirprogrammet. Nu bad Riisager om to eksemplarer - ét til sig selv og ét til Dronningen.

\section{Sonata da camera}

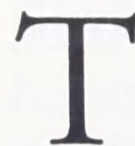
halias havde kun været tilknyttet Seattle Universitet nogle få år $\mathrm{i}$ 1972, men det var længe nok til, at der var blevet skabt en tradition for at afholde middagskoncerter $\mathrm{i}$ universitetsbibliotekets lille auditorium. Sådan en dag med kammermusik i frokostpausen skabte en feststemning, der holdt sig resten af dagen. Tirsdag d. 16. maj var netop sådan en dag, der jo var endnu mere speciel på grund af Knudåge og Åse
Riisagers tilstedeværelse. Først blev der spillet Sonate for flojte, violin, klarinet og cello. Så fulgte Griegs Strygekvartet med Mikael som første violinist og Frances som cellist og programmet afsluttedes med Riisagers Trompet Concertino, som er højt værdsat af trompetister overalt.

\section{Banketmusik}

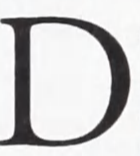
en Danske Klub i Seattle blev grundlagt af danske forretningsmænd sidst i tresserne. Dens formål var selskabelig, men ud over dette også at virke som en dansk repæsentation i forhold til byens forretningsverden og som vært for danskere, som kom til byen i embeds medfør. Som eksempler på sidstnævnte kan nævnes Poul Hartling, Osvald Helmuth, Anker Jørgensen, o.a.

Den Danske Klub afholdt en middag til ære for Knudåge og Åse Riisager om onsdagen d.17. maj, og i aftenens program skulle der som fællessang synges nogle af Riisagers egne sange. Som et dyrebart klenodie havde jeg i mange år bevaret en kopi af Frihedssangen, som jeg havde fàet, da den blev uddelt fra en lastvogn i de uforglemmelige befrielsesdage. Det var før det blev kendt, at komponisten var Riisager. Selvfølgelig skulle den på programmet, og alle fik uddelt en kopi af klenodiet. Mor Danmark skulle også helst med, men jeg havde ikke noderne, så jeg smuttede over til Mikaels hus, hvor, som nævnt, gæsterne boede. Under en samtale dér siger Riisager pludselig:"Vil I gerne have at jeg spiller til?" Jeg havde slet ikke tænkt på, at han muligvis selv ville akkompagnere, og jeg sagde med 
det samme, at det ville være en stor glæde for alle.

Senere i samtalen benyttede jeg lejligheden til at spørge om, hvordan san-gen egentlig var blevet til i de usikre tider, der ledte op til besættelsen af Danmark. Derom berettede Riisager: "Mogens Lorentzen bankede en aften på døren og sagde, at han havde skrevet en sang til Danmark. Vi kiggede på teksten med det samme og blev meget rørte. Det eneste sted, vi anså som problematisk, var udtrykket 'Nordens Arkipelagos' for det danske ørige. Men vi lod det stå, og det blev jo også accepteret. Melodien kom nærmest af sig selv, som om ordene sang sig selv, ligesom der står i teksten: "Lavmælt i fortrolig tale". Noderne bærer da også instruktionen "fortællende", og er uden taktstreger for at understrege den fleksible ordrytme, der er vigtig for den rette fortolkning. Når man så dertil føjer mindet om klangen af den unge Aksel Schiøtz' stemme forstår man, hvordan den sang hjalp et helt folk til at finde en ny værdighed.

På den tid var Riisager ansat som kontorchef $\mathrm{i}$ finansministeriet og blev derfor ofte inviteret til forskellige regeringsmøder, bl.a. til en middag, hvor statsminister Thorvald Stauning blev hædret. Riisager, som på det tidspunkt bedst var kendt af den store befolkning som Mor Danmarks komponist, fortalte, at han under middagen holdt en tale for den aldrende statsmand, hvori han kaldte ham "Far Danmark", hvilket Stauning blev meget rørt over.

Alle tilstedeværende ved Den Danske Klubs middag blev også rørte. Her var komponisten jo næsten på hjemmebane, og alle følte den specielle varme inderlighed, der ligger i Mor Danmark - sangen, måske også forstærket af afstanden til moderlandet og ydermere med komponisten ved klaveret. Hele aftenens program med taler og sang var præget af en hjertelighed, som til sidst blev udløst i Frihedssangens begejstring.

\section{Sonata da chiesa}

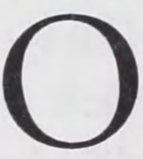
$m$ fredagen d. 19. maj var der Riisager-kammerkoncert i den danske kirke, St. Johns. Programmet var udvalgt for de mere kræsne musikelskere. Først spilledes Lille Ouverture for Strygere, der i sin elegante diverterende lethed bærer præg af ånden i fransk ny-klassissisme. Trompet Concertinoen blev gentaget og til sidst opførtes Variationer over en Sarabande (af Hertugen af Orléans, 1415), et meget smukt værk. Efter koncerten var der kaffe i salen nedenunder. Og nu var det Ase Riisagers tur til at komme i rampelyset, idet der samme sted var en udstilling af tolv af hendes meget smukke akvareller. Det var billeder med lys og lykke, især i en række hav-og forårsmotiver.

\section{Divertimenti}

$\mathrm{K}$ nudåge og Åse Riisager nåede også at se lidt af Staten Washington. En tur gik til Stillehavet, ca. to og en halv times kørsel væk, hvorunder man midtvejs har lejlighed til at se statens regeringsbygninger domineret af Kapitolets kuppel i hovedstaden Olympia. Søndagen før parrets afrejse gik turen til det overvældende og fritstående 


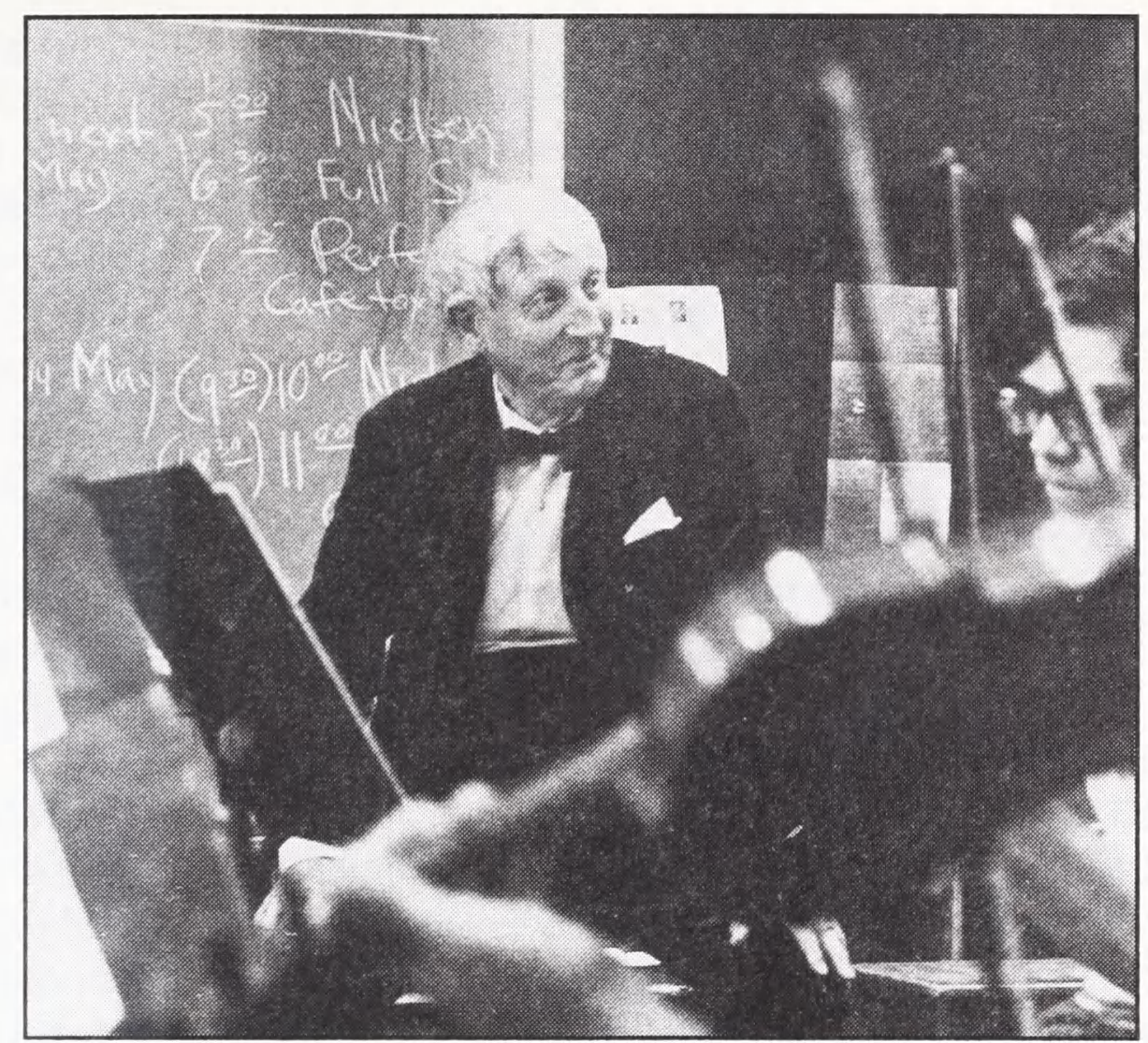

Riisager omgivet af Thalia's ungdomsorkester i maj 1972.

bjerg, Mt. Rainier (ca. 4.600 m), hvor man kører op i en højde af lidt under $2.000 \mathrm{~m}$. På den tid af året og i den højde var det dårlig nok forår deroppe, og af bjælkechalet'et var det kun tagryggen, der ragede op af snedyngerne. Lige uden for nationalparkens indgang standsede vi ved en souvenirbutik, og her blev Riisagers opmærksomhed fanget af en stærkt koloreret version af en indianerhøvdings hovedtøj af fjer. Så vi måtte jo tage et billede, så det kunne bevises, at efter bare nogle få ugers ophold i "Det Vilde Vesten" var han faldet til.

\section{Les adieux}

fter nogle dage fløj Knudåge og 4 Åse hjem og skrev fredag d. 26. maj et brev, der fortalte, at de var kommet godt hjem og takkede deres nye venner for den dejlige tid i Amerika. De kunne simpelthen ikke undgå at få nye venner, disse to dejlige mennesker, der spredte glæde over de enkle, men evige værdier i livet - børn, familie, natur, musik, kunst, folkeliv, legender, fortællekunst, humor, overraskelsesmomenter, m.m. Måske er sammenligningen med H.C. Andersen ikke helt hen i vejret! Riisager kom til en af mine timer og jeg satte en plade på med uddrag fra hans ballet Etude. Studenterne stillede forskellige spørgsmål om dans og musik, og han gik så højt op i at svare at han demonstrerede ballettrinene, der svarede til 
Czernys berømte fraser, hvorpå hele værket er baseret. Vi brød alle - også danseren - ud i bifaldende latter. Sådan var besøget hele vejen i gennem; hvad enten det nu var musikken eller æresgæsterne, overalt efterlod de menneskevarme og glæde. Musikken er stor i sin enkelhed det var komponisten også.

\section{Efterskrift}

$\mathrm{B}$ esøget endte ikke med gæsternes hjemrejse. Ikke alene gav det Thalia og Seattle Universitets musikafdeling en følelse af at have nået en ny højde, men der var også flere håndgribelige resultater.

Riisager var imponeret over Seattle Universitets A Capella Kor under Lou Kellys ledelse, og han foreslog, at det skulle komme til Danmark for at deltage i 4 . juli højtidelighederne i anledning af U.S.A.s uafhængighedsdag. På hans anbefaling til Rebild-Komitéen skete det to år senere i 1974 og Dronning Magrethe var til stede. Det var en utrolig oplevelse for os alle, og ikke mindst for de 65 unge mennesker, der for de flestes vedkommende var i Europa for første gang. Der blev også afholdt en korkoncert i denne forbindelse, i hvilken det store nummer var Riisagers Dansk Salme, hvori koret forenede kræfter med Ålborg Symfoniorkester under ledelse af Jens Schrøder. Denne koncert blev transmitteret af Danmarks Radio.

Forbindelsen med Dronningen blev fornyet i 1976, da Hendes Majestæt kom til Seattle i anledning af tohundredeåret for USAs grundlæggelse som nation. Som et led $i$ arrangementet sang koret et underholdende program, der også inkluderede en ny komposition af mig til Dronningens ære og som en velkomst til Seattle.

Besøget i Seattle havde også eftervirkninger på den anden side af Atlanten. Riisager skrev efter sin hjemkomst, at man i tidligere tider havde anset Sarabande Variationerne for vanskelige, men at man, efter at det blev kendt, at de var blevet spillet på amerikaturen, begyndte at udvise ny interesse for dem.

Thalia-Scheremetiew-biblioteket blev i forbindelse med Riisagers besøg udstyret med toogtyve af komponistens værker, som altså dermed er et vedvarende minde om begivenhederne. Heriblandt findes Bold Overture og Flies in the Buttermilk (and elsewhere) "Fluer i kærnemælken (og andre steder)". Riisager var blevet så glad for de amerikanske folkemelodier, at han skrev denne suite efter hjemkomsten og tilegnede den "To my young friends in Thalia". Dette værk må være en af komponistens allersidste kompositioner, - muligvis den sidste.

Det er en livets mærkelige sider, at de store ting, der sker med mennesker, eller de store ting, de opnår efter kort tid, ikke er synlige på overfladen. Men inden i dem fortsætter ekkoerne uden formindskelse. Derinde i mere end tusinde mennesker ligger det store monument for Knudåge og Åse Riisagers besøg i Seattle i 1972. 